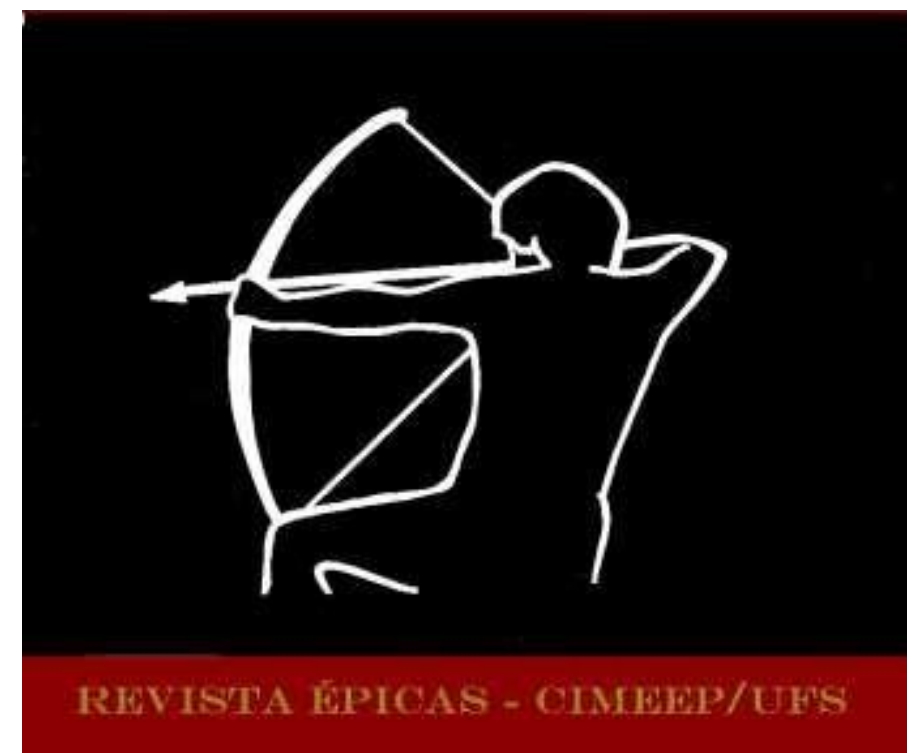

RAMALHO, Christina. About epic subject: heroes, heroines and anachronism. In: Revista Épicas. Ano 5, N. 10, Dez 21, p. 162-179. ISSN 2527-080-X

DOI: http://dx.doi.org/10.47044/2527-080X.2021v10.162179

\title{
ABOUT THE EPIC SUBJECT: HEROES, HEROINES AND ANACHRONISM
}

\author{
SOBRE O SUJEITO ÉPICO: \\ HERÓIS, HEROÍNAS E ANACRONISMO
}

ABSTRACT: Considerations about a special subject, the epic, or, in other words, the hero and/or the heroine who are the protagonists of some long poems which talk about history and myth in a literary way, with or without traces of anachronism. We will consider the evolution of concepts of subject as a fundamental category for literary studies, the evolution of the epic genre itself, the epic representation of women and the anachronism as a possible presence in epic poems. Illustrating our reflection we will comment some epic poems which integrate the epic expression in English: The faerie queene, by Edmund Spenser; Paradise regained, by John Milton; The Rape of the Lock, by Alexander Pope; The Fall of Hyperion, by Keats; Christ, by Gavin Bantock; and South America. Mi hija, by Sharon Doubiago.

Keywords: Anachronism. Epic subject. Cultural identity. Epic heroism. Gender.

RESUMO: Considerações sobre um tema especial, o épico, ou seja, o herói e/ou a heroína que são protagonistas de alguns longos poemas que falam de história e mito de forma literária, com ou sem traços de anacronismo. Consideraremos a evolução dos conceitos de sujeito como categoria fundamental para os estudos literários, a evolução do próprio gênero épico, a representação épica da mulher e o anacronismo como uma possível presença nos poemas épicos. Ilustrando nossa reflexão comentaremos alguns poemas épicos que integram a expressão épica em inglês: The faerie queene, de Edmund Spenser; Paraíso recuperado, por John Milton; O estupro da fechadura, de Alexander Pope; A Queda de Hyperion, de Keats; Cristo, de Gavin Bantock; e América do Sul. Mi hija, de Sharon Doubiago.

Palavras-chave: Anacronismo. Assunto épico. Identidade cultural. Heroísmo épico. Gênero.

In this text, we will reflect on the presence of heroes and heroines as protagonists of epic poems or even of some long poems which talk about history and myth in a literary way, not necessarily considered as epic by the traditional critical approach. These heroes and heroines will be treated here as epic subjects. 
Beginning by considering different concepts of the subject category as an important way to understand the evolution of the epic subject itself, this approach includes reflections on possible forms of anachronism and, also epic women representation. Illustrating our reflection, we will mention and comment about some poems that integrate the epic expression in English language: The faerie queene, by Edmund Spenser; Paradise regained, by John Milton; The Rape of the Lock, by Alexander Pope; The Fall of Hyperion, by Keats; Christ, by Gavin Bantock; and South America. Mi hija, by Sharon Doubiago. This approach will metonymically reveal the timeliness and the actuality of the epic genre, even if in renewed forms Our main goal is to contribute to an up-to-date view of the epic genre, in its peculiarity: the heroism.

Introducing the question, it is important to consider that, through the ages in the West, Greek and Roman epic tradition, models of epic heroism can be taken, by other poets, anachronistically, in the sense of limited imitation, or through a creative form of anachronism. About the anachronism, Srinivas Aravamudan says that:

The subject of anachronism (more or less everybody, because no living localized human being can fully occupy the hot seat of objectivist historicism, even when speaking in its name) goes beyond historicism by refashioning an explanation of himself or herself in the wake of the multiple futures that exist in the now, rather than by yielding to the tyranny of a totalized now that purportedly lead to a singular future (ARAVAMUDAN, 2019, p. 351).

So, when we visit categories as "subject" and epic heroism, we must know that some type of anachronism will be present, because the human being is always part of a history as well all literature works relate to literature as innate human expression. According to Aravamudan, "The return of anachronism is nothing more than the return of the subject, which might console some even as it alarms others" (ARAVAMUDAN, 2019, p. 351). This is the moment of returning to the aim "subject", because we need to identify the moments in which epic production manages to make apparently anachronism manners of rethinking the inscription of the human being in the world.

Although Descartes, Kant, Marx, Nietszche, Heidegger, Freud, Beauvoir, Lacan, Derrida, Foucault, Kristeva, among many other, have exhaustively discussed the theme subject and came to countless subject theories, if we think about a special type of subject as the epic one, it is not necessary to take up all the evolution of these theories in their encircling and conceptual nature (philosophical, sociological, anthropological, etc.). It is utterly essential to consider that visiting the epic hero and the epic heroine categories implies in reflecting theoretically upon the subject's question, since both will be understood as such from their performances as subjects of the action and of the discourse. As an epic hero and even an epic heroine is above all, cultural representations of human being, to study subject as a cultural category seems to be a productive option.

The epic subject has specific characteristics or particularities, some of which are intimately related to the displacement action, inherent to the narrative structure from which this kind of manifestation is composed. The epic subject is, undoubtedly, a "being in action", and for this action it gains a social-symbolic 
value: to represent the historical-existential inscription of the human being that managed to accomplish a "journey" in the world, integrating to this journey a mythical experience that intensifies the symbolic value of the journey.

Therefore, in terms of an investigation which centre of interest is the difference of gender, susceptible to be recognized in the epic subject category, one has to consider how the evolution of the ways of human being's performance in society allowed epic heroism to stop being exclusivity male and became to be an opened possibility to women, which way of social performance is suffering radical changes in the last two centuries. In an even broader sense, we cannot forget that human being, in our days, has other types of confrontations to overcome. So, being a hero or a heroine today is not the same from the past. Müller, talks about some current heroic experiences that we live in our more common dreams (or nightmares):

In many of our dreams we are also in route. At the beginning of a "trip" towards ourselves we are suddenly in unknown cities, we walk by isolated areas or we get lost in forests and mazes. Sometimes, we cannot even leave: we are without the luggage, without the documents or without the ticket, the car does not work, we lose the bus by seconds. In another occasion, we lose the money on our way or we look desperately for the car parked somewhere. The dreams we have thus show our fears and conflicts, which are opposed to the "heroic road" and that make the flow of creative life so difficult for us to follow ${ }^{1}$.

This kind of anti-heroism seems to be incompatible with an epic hero, but, otherwise, we can think that the concept of the epic subject may follow the evolution of the subject concept, because when an epic poem represents the human being and all its heroic acts, one type of subject is also represented. And, if we know that the concept of subject has been changing through the ages, we cannot study an epic poem using the same values and points of view of ancient times, under penalty of being anachronistic theoretically. Stuart Hall, with his theories about the subject, helps us to understand the very presence of heroism in the epic through the ages. Let us recover some of his considerations.

Stuart Hall refers to three cultural subject conceptions: the Enlightenment subject, the sociological subject and the post-modern subject (HALL, 2002, p. 10). The first subject was constituted from Descartes' theoretical constructions who, postulating the dichotomy matter $\mathrm{X}$ mind, made human being the subject of a rationalized life experience. This postulation deconstructed human being's subservience to the religious logics that castrated self-knowledge with the purpose of exercising control upon human behaviour. For this reason, before this rational conscience of existing in him/herself and by him/herself, or even what Hall calls Enlightenment subject, the human being could not understand him/herself as a subject. Even in the classic anthropocentric time, it would fall to the philosopher to guide human beings towards intelligible knowledge,

\footnotetext{
${ }^{1}$ Original in Portuguese: "Em muitos dos nossos sonhos também estamos a caminho. No começo de uma "viagem" em direção a nós mesmos vemo-nos de repente em cidades desconhecidas, caminhamos por regiões isoladas ou nos perdemos em florestas e labirintos. Às vezes, nem conseguimos partir: estamos sem a bagagem, sem os documentos ou sem a passagem, o carro não pega, perdemos o ônibus por questão de segundos. Numa outra vez, perdemos o dinheiro no caminho ou procuramos desesperados o automóvel estacionado em algum lugar. Os sonhos que temos mostram assim nossos medos e conflitos, que se opõem ao "caminho heroico" $e$ que tornam tão difícil para nós seguir o fluxo da vida criativa" (MÜLLER, 1997, p. 19-20).
} 
diverting them from the sensitive path which, in the philosophical perspective, would alienate the being from knowledge. With Christianity, religion assumed this guiding role. And it has been like that for practically ten centuries. Let's think about this already bringing to light a famous epic poem: Paradise recovered, by John Milton (1608-1674).

In an epic poem as Paradise recovered, situated precisely on this border between Christian perspective and the Enlightenment subject, we can observe how religion ruled the question of human identity. Being was a question of obedience or not to God, as we can see in the epic proposition, which opens the First Book:

\author{
I, Who erewhile the happy Garden sung, \\ By one mans disobedience lost, now sing \\ Recover'd Paradise to all manking, \\ By one mans firm obedience fully tri'd \\ Through all temptation, and the Tempter foil'd \\ In all his wiles, defeated and repuls't, \\ And Eden rais'd in the wast Wilderness. \\ (MILTON, 2014, p. 54)
}

The epic heroism in Milton was, itself, different from the epic heroism of Greek and Roman heroes. The main battle to be won was not a battle of war, but a battle against the forces of evil, against temptation, which diverted the man of God. In the same way, the epic muse was not the same of Homeric and Virgilian epics. For this reason, the epic voice of Milton's poem claims:

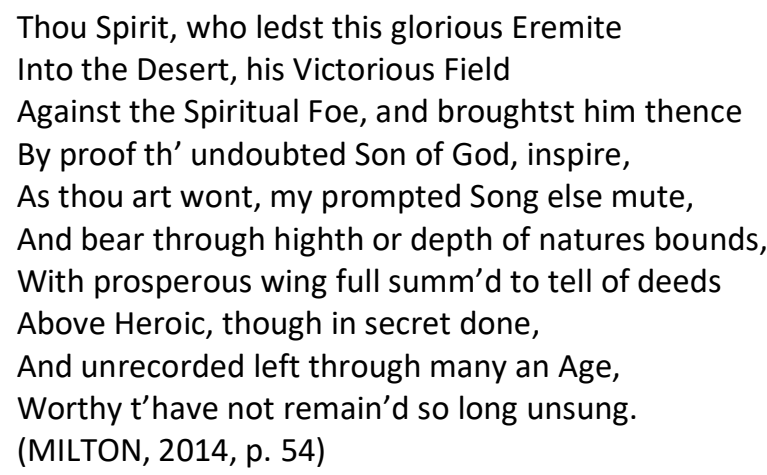

Despite the ideological distance from the classical tradition, Milton, in his poem, makes use of many classic references, which is sustained by the concept of anachronism as a way of belonging to a tradition. But in this case only a more in-depth study could account for the examples that Milton's work presents in terms of dialogue with the Homeric and Virgilian tradition. Let's come back to Hall.

Through Descartes, the existing conscience made human being the centre of the philosophical knowledge. This Enlightment subject, self-centred, male and individualized, was ratified by John Locke's thought, for whom the individual was "sovereign" for having the possibility of guiding his conscience towards past, present and future, to rationally organize his existential experience. Curiously this new experience 
provoked a certain reaction to classic and religious epic poetry, and designated a series of satirical epic poems, called "mock-epic", among which stood out The Rape of the Lock. A hero-comical poem (1712-14), by Alexander Pope (1688-1744). Part of its opening text show us how Pope faced the religious epic tradition ironically:

The Machinery, Madam, is a term invented by the critics, to signify that part which the Deities, Angels, or Dæmons, are made to act in a poem: for the ancient poets are in one respect like many modern ladies; let an action be never so trivial in itself, they always make it appear of the utmost importance. These Machines I determined to raise on a very new and odd foundation, the Rosicrucian doctrine of Spirits.

I know how disagreeable it is to make use of hard words before a lady; but it is so much the concern of a poet to have his works understood, and particularly by your sex, that you must give me leave to explain two or three difficult terms. The Rosicrucians are a people I must bring you acquainted with. The best account I know of them is in a French book called La Comte de Gabalis, which, both in its title and size, is so like a novel, that many of the fair sex have read it for one by mistake. According to these gentlemen, the four elements are inhabited by Spirits, which they call Sylphs, Gnomes, Nymphs, and Salamanders. The Gnomes, or Dæmons of earth, delight in mischief; but the Sylphs, whose habitation is in the air, are the best conditioned creatures imaginable; for, they say, any mortal may enjoy the most intimate familiarities with these gentle spirits, upon a condition very easy to all true adepts, - an inviolate preservation of chastity.

As to the following cantos, all the passages of them are as fabulous as the Vision at the beginning, or the Transformation at the end (except the loss of your hair, which I always mention with reverence). The human persons are as fictitious as the airy ones; and the character of Belinda, as it is now managed, resembles you in nothing but in beauty (POPE, 1968, p. 141).

Parodies and comic recreations were forms of opposition to a tradition in which the human being could not recognize itself. As Aravamudan says, "any analysis of anachronism, whether of event or of period, has to take into account the function of dating that makes such discernments possible" (ARAVAMUDAN, 2019, p. 334). These creative ways of taking tradition back to dismantle or deny it were a trend at a time when the human place was dismantled as well. They were a Cartesian way of trying to order the new from the negation of the old. At the same time, this denial, as the text presented in "English Literature - Notes The Rape of Lock: A Mock-Epic" (2020) says, may seek in what is still older a way of opposing matter than the focus of satire:

The Rape of The Lock is an excellent example of mock-epic or heroi-comical poem in English Literature. The epic had always been considered as the most serious of literary forms; it is grand in style, deals with weighty subject; Its personages are dignified. For example- Homer's Odyssey, Virgil's Aeneid, and Milton's Paradise Lost.

In contrast, the mock-epic is a poetic form which uses the epic structure but on a miniature scale, and has a subject that is trivial and unimportant. The purpose of the mock-epic or mockheroic poem is satirical. In fact, a mock-heroic poem is not a satire on poetry itself, but the target of the attack may be a person or an institution or the whole society. Though, the subject of such a poem is trivial or unimportant, the treatment of such subject is heroic or epic and such exaggeration of the trivial naturally arouses laughter. 
Alex Eric Hernandez, on the other hand, in "Commodity and Religion in Pope's The Rape of the Lock" presents us with one important aspect of this work of Pope:

Pope criticizes those who would commodify the ethical heart of Christianity by making the provocative claim that, like the powders used to beautify Belinda, the Bible may become simply another accessory for those positioning themselves socially - or, perhaps more insidiously, it becomes an ideological tool for a rapidly industrializing society (HERNANDEZ, 2019, p. 569-570).

Pope, therefore, rationalizes faith, linking it to a material idea of consumption, which, therefore, deconstructs the heroic epic subject pattern seen in Milton. Somehow, through a comic perspective, Pope achieves what, in the figure of the epic religious hero, would actually be artificial, since the religious values, in turn, would also be so.

The presence of satirical works that dialogue with or take ownership of the epic is a relevant sign for understanding the transformations in the very vision of the relationship between subject and society and the very concept of subject itself. And in this sense, the epic hero is, in a way, an emblematic figure, since he represents an idealized pattern of conduct and character. Tom MacFaul, in the article "The Butterfly, the Fart and the Dwarf: the Origins of the English Laureate Micro-Epic", reflects on Pope's use of the ancient epic to criticize the heroic values of his time:

Certainly, part of the effect of the poem's miniaturization of the heroic is to suggest a general diminution and aestheticizing of heroic values at Elizabeth's Court, as Robert A. Brinkley points out, but the idea of heroic action being vitiated and entangled by webs of power beyond a hero's ken allows the heroic code to be both valued and treated as doomed. This kind of mock epic has considerable congruity with the attitude of the truest epics, such as the Iliad and the Aeneid (MACFAUL, 2007-2008, p. 146).

Observing this point of view, we can remember other one through "English Literature - Notes - The Rape of Lock: A Mock-Epic" (2020): "He does not want to mock the form of epic rather his aim is to mock his society in its very failure to rise to epic standards. He exposes the meanness of his age's nobility by contrasting it with the bravery and noble height of traditional noble heroes". In some way, therefore, the model of the classic epic hero can be emulated to think about the new subjects that will appear in the epics through the ages. And this emulation sometimes tends to follow the path of emptying the classic model itself, now it can be a creative resource that appropriates the old to design the new. And, in Pope's poem, something else stands out: the protagonism is given to a woman, Belinda ${ }^{2}$, who turns out to be a kind of symbol of what, according to the poem, was the real face of Religion: a fashionable thing. In "episodes that conflate religious iconography with the ideology of capitalist mercantilism" (HERNANDEZ, 2019, p. 572), we can see the investment in the rationalization of an experience that, being religious, would be mythical-mystical. But this rational subject would not be able to resist the changes in the world for a long time.

${ }^{2}$ In real life, Arabella Fermor. 
Turning to Hall's ideas, the complexity of modern societies diluted the Cartesian subject's action power and brought to surface the social injunctions and Darwinian biological determinisms, decisive factors, so that the individual displacement towards the social would be processed. Individuality became, then, a data in the complexity of the human-existential experience, which orientation followed, now, the courses of a more cultural apprehension of the relationships between the individual and society. In this process, however, the effect of the construction of a typically Cartesian thought could still be felt, because, in an evident dualism, it fell to psychology the individual subject's understanding and to sociology, the social subject's understanding. Lost in the handling of his/her social masks, this sociological subject did not access or integrate his individual dimension. Implicitly, though, the individual mark continued to be a male projection, now added to the racial (white), geographical-cultural (western) and economical (bourgeois) referents.

Names as Percy Bysshe Shelley (1792-1822) and John Keats (1795-1821) situated precisely on this border between the Enlightenment subject and sociological subject, are examples of changings in subject concept. Some classic literary aspects were revisited by them, although in different perspectives ${ }^{3}$. The poem The Fall of Hyperion (1819), by Keats, presents a new vision about the space that the dream could have in an epic poem. And this view certainly influenced the transformations by which the epic genre passed in the XIX's, both in terms of heroism and in relation to the concept of history. Let's look at the opening of the poem:

\section{CANTO I $^{4}$}

Fanatics have their dreams, wherewith they weave

A paradise for a sect; the savage too

From forth the loftiest fashion of his sleep

Guesses at Heaven; pity these have not

Trac'd upon vellum or wild Indian leaf

The shadows of melodious utterance.

But bare of laurel they live, dream, and die;

For Poesy alone can tell her dreams,

With the fine spell of words alone can save

Imagination from the sable charm

And dumb enchantment. Who alive can say,

'Thou art no Poet may'st not tell thy dreams?'

Since every man whose soul is not a clod

Hath visions, and would speak, if he had loved

And been well nurtured in his mother tongue.

Whether the dream now purpos' $d$ to rehearse

Be poet's or fanatic's will be known

When this warm scribe my hand is in the grave.

When Keats rethinks the place of poetry it provokes the Cartesian's own logical vision of the world. It was clear that the division between rational and subjective perspectives of life was not enough to give some signification for human presence in world. In that context, epic poetry would have to change its own

\footnotetext{
${ }^{3}$ Gilbert Highet compares Keats compares Keats to Shakespeare and Shelley to Milton (A, 187-199).

${ }^{4}$ Web access (see Bibliography).
} 
perspective, mainly about themes as history, heroism, society. Through Vicent Newey's presentation of the history of the creation of The Fall of Hyperion - with emphasis on the construction of the characters Saturn and Oceanus, in the first version Hyperion - we can see an example of the conflict between these two perspectives:

This was also a time of intense intellectual activity. He was reading and carefully annotating Paradise Lost from late 1817 on, and took Cary's translation of Dante's Divine Comedy with him on his Northern tour of summer 1818. This literary study was part of a sustained effort of exploration and insight that embraced wider aesthetic issues, current events, and the course of human affairs. Keats began Hyperion in fall 1818, abandoned it in mid-sentence by April 1819, began a reconstruction as The Fall of Hyperion (NEWEY, 2001, p. 70).

In reviewing the grand march of intellect (KL 1.281-82), Keats took pains to praise Wordsworth's poetic "Genius" over Milton's "Philosophy." Oceanus's philosophy is decidedly un-Miltonic, because un-theological. Questions of good and evil, of vice and virtue, of moral action, of damnation or redemption from sin, do not figure in his account of universal destiny to progressive "perfection." (NEWEY, 2001, p. 73)

Keats' process of creation involves a profound reflexion about of Literature's role. Like Dante, a Ilyrical/narrator is the hero who will face the challenge of uniting reason (the result of the consciousness of epic creation) and imagination, which corresponds to a content of pain. His guide during his travel was the muse Moneta, who emphasizes, in some way, that suffering is a necessary component to achieve a truly artistic vision. In the Canto II, Moneta reveals that there is an intangible plan, which the human only touches with the imagination:

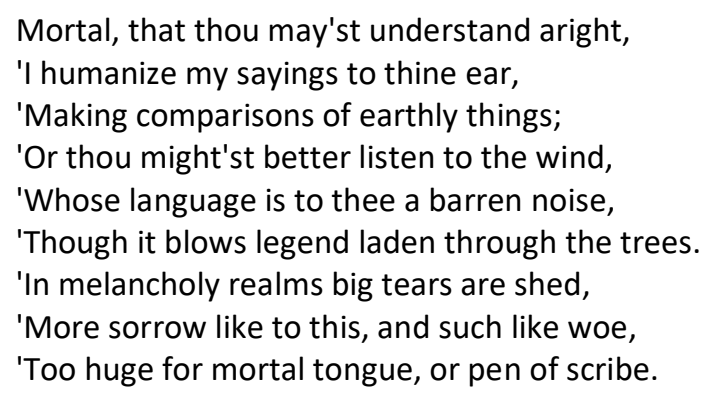

In order to resolve this conflict, the human being will need to merge scientific knowledge with the observation of social reality, still opening space for what the language offers in terms of imaginative sensitivity. But the weight of social disorder will be increasing and will lead to the impossibility of reconciliation between the sociological subject and in the tradition represented by the Enlightenment subject.

So, since the end of the $19^{\text {th }}$ century, the impossibility of establishing a unit between the individual and the social projected the subject into a chaotic situation and arose the "isolated, exiled or alienated figure of the individual, put against the backdrop of the crowd or of the anonymous and impersonal metropolis" (Hall 32). Punctual works by artists such as Baudelaire and Kafka highlighted the subject's unusual experience, taken either as a flaneur, or as a dandy, or even as a subject outside his/her body. The moving, as a lost body 
in space or as a mind outside his/her body, revealed the being's decentering and evidenced the metonymical character of the human-existential experience, in other words, the subject's identity being fragmented, any kind of centering became impossible, or even better, a multiple centering took place.

According to Stuart Hall, "a displaced structure is the one which centre is displaced, not being replaced by another, but by a plurality of centres of power" (HALL, 2002, p. 16). Thinking about this decentered being, defined by him as a post-modern subject, Hall recognizes five theoretical postulations that occurred to transform the Enlightment subject into post-modern subject, passing by the sociological subject: the Marxist structuralism, represented mainly by Louis Althusser; the discovery of the "unconsciousness" by Freud and subsequent visions, such as the ones of Lacan; Ferdinand de Saussure's linguistic structuralism and posterior thoughts, such as Jacques Derrida's and alike thinkers, who reached the multimodular feature of the words and the real impossibility of an individualized discourse; Michel Foucault's philosophical and historicist studies about the power mechanisms and disciplinary controls, which objective is to offer docility to human being; and, finally, the theoretical postulations and the feminist natured social movements, such as the ones of Simone de Beauvoir and Julia Kristeva's, among other, which deconstructed culturally ingrained dichotomies as, for instance, "the public and the private" and addressed their thought and action to the apprehension of the formation of the sexual and gender identities.

All these theoretical incursions concerning human existence ratified and, in a certain way, impelled the refragmentation process of the identities already fragmented by the incongruity between the individual and the social. Although among the "bits" of the Enlightment subject and sociological subject one could still glimpse, with a certain easiness, the marks of the male/white/ Eastern/bourgeois centering, it cannot be denied that this chaotic process began the extermination of the singularities that determined in a valuing, hierarchical and exclusivist way, categories such as "class" and "gender".

Because of all of this, to consider about the epic subject's course as one of the symbolic categories of the human-existential experience ends up by making clear the recognition that if the male Cartesian subject was deconstructed by the effect of human life's sociological orientation, it did not fall to this sociological orientation to, in fact, reorganize the society, since only the formulation of the social injunctions was bound to it, not the redistribution of the social roles, which, in turn, continued to be restricted to the domain and the male elite control.

The passage of the structuralist thought towards the post-structuralist one promoted, indeed, if not a redistribution, at least a deconstruction of the sources and forms of power. History, for instance, that so far had had a patriarchal orientation for the apprehension and reading of the facts, was compelled to a redefinition of its philosophical and theoretical criteria. Hence the possibility of rethinking the category of the historical subject and, consequently, reviewing the formation of national identities. Being the postmodern subject, as seen, a decentered subject, it will be, as Homi K. Bhabha (1998) proposes, in the amidplace, that we will rediscover him/her. If the amid-place brings with itself the marks of the differences, it cannot stop integrating to its complex structure several dimensions of the human-existential experience, 
among them, the mythical one. It is in this aspect that the epic hero and heroine's figures acquire relevance again, taken here as epic subjects. The first manifestations of the epic discourse in western literature revealed heroes as subjects in displacement, to which was attributed the role of circulating between the historical and wonderful plans and act in both so, as to be the agent of the fact and the myth. Hence, perhaps, the revelation of being the epic heroism a perfect allegory of the conquest of this amid-place proposed by Bhabha ${ }^{6}$, in other words, the epic subject, transiting through the historical and mythical dimensions of the being, lives an enriching experience that projects him/her simultaneously in the national and in the universal, in the field of the historical-cultural injunctions and in the field of the mythical-symbolic injunctions, existence that, as a result, allows him/her the symbolic conquest (because literary) of an individuality.

Joseph Campbell (1988) defined the profile of heroes of mythical narratives from the most diverse origins. According to Campbell, the heroic performance presupposes a spatial displacement, a predisposition and a competence to act outside of the sacred places, outside home's cozy dimension, and to be launched to the unknown space of the "dense forest." The performance in the unknown physical space stressed the nomadic character and the originality of the heroic feats. From the primitive hero that killed monsters throughout the world, to the spiritualized hero, such as Moses, whose attribution was to spread new knowledge to his people, the most archaic heroic mission included the facing of the survival dualities.

Campbell, ratifying the dichotomous vision of patriarchal roots, refers to the cultural injunctions that conditioned women's existence to immobility. Although, Campbell's defined heroes as "people", his considerations refer implicitly to a natural veto to women's spatial displacement. Therefore, it is convenient to reflect about the impediments culturally imposed to women in the transit towards epic heroism.

Since the beginning of the Western classic cultural formation until the Cartesian subject's validity, it would not be possible - with rare exceptions - to attribute the epic heroic function to a woman. Of course, imaginarily, women could even assume warlike postures. An example of this is contained in the Greco-Roman mythological reports that highlight the actions of the Olympus goddesses. Even in the reality dimension, women that broke up with the paradigms of the feminine behaviour and rushed into the "dense forest" can be highlighted. However, as seen in the previous chapter, when I dealt about the phenomenon of the cultural circularity of the myth, literature itself reproduced, in a wide range, the versions of myths that referred to masculine heroic feats, while, many times, it ignored less orthodox versions in which the feminine feats darkened certain paradigms.

In general, woman's role in the heroic feat was the one-off being the receiver of the domestic referring, peacemaker of the feelings that could permeate man's heroic experience, such as fear, weakness, boredom and doubt. Knowing that the "sacred place" remained kept by the woman facilitated the execution of the hero's cyclical course: departure, accomplishment and return, besides softening the overcoming of

\footnotetext{
${ }^{6}$ However, it is convenient to explain that we differentiate the epic heroism from other types of heroism when I recognize in the former the requirement of the double performance in the historical and marvelous plans, in other words, the epic heroism is n ot a fictional construction, but, in fact, an incursion in the human-existential experience.
} 
tribulations. Therefore, performing as co-subject of the action, the woman neither lived the fullness of displacement nor even attempted the challenge of the unknown. Culturally, though, the idea of facing and overcoming the challenge was perpetuated as a way of growth, deservingness and salvation. Stagnated, the woman accomplished her fate of subservience and silence.

Surmounting a tribulation had, and still has, in the heroic perspective, a "prowess" character. Physically natured, when the challenge represents the need to use an extraordinary force, many times involving the saving or rescue of lives; or spiritually natured, when the challenge consists in the competence to deal with the superior level of human spiritual life (Campbell 1988) and to convert the experience into a message to be spread, the heroic feat, up to the seventeenth century, required an adventurous spirit, explicitly masculine. Therefore, woman's passivity and staticity denied her the possibility to face heroic tribulations, falling to her only the domestic ones, which obviously did not have the same status of the former. On the other hand, all the women's actions towards breaking this dichotomic conditioning were historically and culturally veiled.

In view of that, the construction of the subject's epic-heroic identity was a male attribution, and, for that construction, there were still the basic requirements for a heroic career: loyalty, temperance and courage. From his feats or adventures, not only the individual identity was marked, but the national, in other words, the subject's heroic performance was also coated by a cultural attribution: to establish the bond between the individual and his country. Hence it is also understandable that, because of the need of construction and reassertion of the national identities, many of the epic heroes, all of them men, portrayed in neoclassical and romantic epic poems, have been extracted from the historical context and not from the mythical one any more (as in Ancient Times).

When this heroic performance was clothed by the epic character, in other words, when those feats or adventures extrapolated the historical plan and gained mythical adherence, heroism had its value even more valued culturally, since the epic hero's conquests became conquests of a collectivity represented in and by him.

So, acquitted from displacement, woman was psychologically stagnated and dependent, immature, therefore, for the discovery of herself. On the other hand, the historical registration of the female experience was also neglected, as it was unable to negotiate the real and mythical dimensions from which a cultural identity is constituted. It was starting from the conquests pointed by Stuart Hall that the subject's identity decentered from the male and opened up to the multiple experiences of existence, in which the feminine space and displacement conquest was included.

Today, the subject's displacement, susceptible of being allegorically represented either by the epic hero or by the heroine, seems to ratify what Homi K. Bhabha calls "strangeness". Beyond the limits of the sacred place, especially because this sacred place was diluted in the verification of the globalized hybrid 
space, epic hero and heroine can live the experience of the unusual, of the unhomeliness ${ }^{12}$ and to act, as Anazildo V. da Silva (2002) registered, in the sense of "experiencing the chaos".

Regarding the aforementioned information, it is not outrageous to affirm that woman never existed as an Enlightenment subject or as a social subject, because as a matter of fact, she always acted as a cosubject. Only when the gender category began to be theoretically and critically thought and, in the historical plan, women's actions started to have cultural representation and she could receive a subject identity. What turns this question more complex is that this possibility "of being" - besides the co-existence - was a conquest chronologically simultaneous to the "not-being" idea or to the subject's denial as a possible representation of human identity. Although, we do not have here the pretentiousness to define or redefine the subject as an encompassing theoretical-critical category, it is possible to leave an open reflection. What is more cautious and legitimate: to ratify that a woman cannot be read as an Enlightenment subject or sociological subject, since she has always been a co-subject in History, or to propose that the Enlightenment subject and the sociological subject, as they were defined, are not sufficient theoretical-critical categories to read the human-existential experience through times? In other words, is this the moment to accept concepts, leaving woman, as a gender category, aside from any revisionism at theoretical level, or to go more thoroughly and transgress the concepts themselves as a means to rethink women's performance in the world, starting from other conceptual parameters concerning to what is, in fact, to exist?

Probably, at the level of the encompassing argument upon the experience of "existing" it is quite possible to practice this conceptual revisionism. However, when one talks about an epic subject, this revisionism is unfeasible, since the study is sustained by the works in fact produced. There's an undeniable fact: Western literature's canonical history had presented, in its course up to the eighteenth century, very few epic poems whose epic subject would be a woman. In other words, the epic co-subject condition is a historically irreversible fact. But there are poems as The faerie queene (1589-1596), by Edmund Spenser (1552-1599), that invite us to think about the meaning of women presence in old power structures. In the Book Three (288), for example, Chastity is personified by a female figure, Britomartis:

\footnotetext{
It falls me here to write of Chastity, The fayrest virtue, far aboue the rest; For which what needs me fetch from Faery Forreine ensamples, it to haue exprest? Sith it is shrined in my Soueraines brest, And formd so liuely in each perfect part, That to all Ladies, which haue is profest, Neede but behold the pourtraict of her hart, If pourtrayd it might bee by any liuing art.
} 
Establishing a dialogue with Ariosto's epic poetry and having as explicit references Homer and Virgil poems, Spenser realized, with The faerie queene, made a great mixture of values and ideologies, opposing the Catholic and Protestant universe in an allegorical work on the virtues and politics that, nevertheless, remained incomplete. The Faerie Queene (or Gloriana), herself, was one of the epic feminine characters that deserves a more in-depth approach, since it is the joyous representation of Queen Elizabeth second. In a culture in which female figures occupy prominent places in power structures, this epic insertion becomes relevant in terms of approaching the presence of women in epic poems.

Returning to the transformations that made us reach the postmodern subject, we think that the subject's fragmentation and his/her decentering did not disable the being's understanding as an individual, but yes, they solved the individuality question: the individual, as a category, no more exists (if it ever did, in fact) as a psychological or social fixed unit, as it is multiple in him/herself, several in one, potencies of being and not-being that are fulfilled from equally multiple and fractioned experiences. Although this vision of the being (or of the subject) is completely antagonistic to the dialectics order perspectives - which, up to quite recently, guided the evolution of the Western thought - since it establishes the existence not of one, but of several subjects in one. There is no way to deny the opening of the vision and the understanding of the human-existential experience arisen from this new approach of the subject's question. The subject's multiplicity is not an identity impossibility, but a new way of identity understanding. Because of this, we can find, in the twentieth century, epic poems as Christ.

Christ (1965), a modern epic poem with 7,000 verses, written by Worcestershire Englishman, Gavin Bantock (1939), is structured in twenty-six parts, each beginning, neatly, by a letter of the alphabet, with epic matter, as the title points out, the life of Jesus Christ. To understand the Bantock many points of view about epic heroism imprinted in the life of Christ had to be changed, mainly those which refer do Christ's image, as we can see in:

Permit me to remember the plagues, though I shall not force the trend to hammer together these words to build a decrepit house.

I shall receive the stones, the holy relics guarded by orthodoxy. And I shall build God again.

Homer was the man who carved the sphinx from the iron beginning of the world; but now there Is no such ground to hammer from, and the sands are strewn with stones chipped from the first monument; so I must seek to be the man who built a pyramid. and may that have the same charm as the thundering silence of sphinx; may that have the same vast serenity of the open eye. 
Christ goes on down a road not yet discovered, a first and lasting fire on a long causeway: so hear him cry down in the raven winds, in the wrinkled creeks of weird elms, and echoing behind the wails of orphans; hear him now, hear him cry down where you are nearest to the world's nerve, or as I, in the heroic dirge of the sea.

(BANTOCK, 1965, p. 1-2)

In 2016, the author published a new version of the poem, with changes that, according to him, generated a new work. In the introduction to the 1965 book, signed by Syed Akbar Husain, we already found an important clue as to the meaning of Christ in the poem: "Thus, the poet declares his intention early on in the poem and makes an especial appeal to the reader do approach this work without prejudical notions either about Christianity, or the story of Jesus Christ as set out in the New Testament" (HUSAIN Apud BANTOCK, 1965, p. ix).

The work focuses specifically on what Husain calls "missing years of Christ's life" (HUSAIN Apud BANTOCK, 1965, p. ix), Presenting scenes related to Christ's relationship with John (the disciple regarded as the most beloved), with Mary Magdalene, with the fallibility of human nature and with its own fallibility. Husain understands the poem as a vision of the maturation of Christ through time, on a journey towards "self-perfection" (Ibidem).

Denying the virginal birth and the vision of Christ as God incarnate, Bantock proposes an epic poem that deconstructs the biblical tradition, to take the heroism of Christ from a fictionalized historical perspective, but legitimized as fiction because Christ is a plurisignificant mythical image. Thus, the work starts from a vision that denies the sacred and takes Jesus Christ as a fallible man, in order to, highlighting aspects of his childhood, defend the idea that "Man must be the maker of his own destiny" (Husain p. $x$ ), to substantiate the final message that "one creed will be replaced by another, one God succeeded by another God, one stage in the Evolution of Man followed by another; but that in spite of all, men must continue to love and suffer" (xiii).

Thus, in Christ, we have a Jesus reinvented from an already known epic-heroic tradition, which is relaxed as a way of valuing what the opening and closing verses of the poem state: "A men at the begginning of my love/for that is the beckoned theme" (1) and "I am forever that singing gull in love's wake:/now I know - that for criming men who adorn fields,/finish echoes in the wind when love beckons" (251), that is: Christ is, above all, Love. Perhaps this is why the poem was republished in 2016 (Unknown Publisher) with the title Christos: Lovesong of the Son of Man: A Poem in Twenty-Six Parts.

As Aravamundan says, when he focuses on the modern use of anachronism: "this is no longer the unitary humanist subject but a fragmented, fragmentary subject, the object, abject, or even reject of historicism, its craven remainder, and indeed an anachronism, but also its pretext, purpose, and incitation" 
(ARAVAMUNDAN, 2019, p. 352). So, when Bantock takes up Christ as epic-matter, he knows that he will have to be upset with many previous fragments, through which the image of Christ that he wants to undo has been built. The Christ, in his poem, is another "subject", with which a modern man can identify himself.

The reflection on the category subject, though, is far from being closed, as the theoretical-critical directions arisen from the insertion of the "machine" component into the subject's multiple structure will be highlighted. About this, Tomaz Tadeu da Silva explains:

One of the most important questions of our time is exactly: where does the human end and where does the machine begin? Or, given the machines ubiquity, would not the order be inverse ?: where does the machine end and where does the human begin? Or, still, given the general promiscuity between the human and the machine, why not consider both questions simply senseless? More than the metaphor, it is the cyborg's reality, his undeniable presence in our milieu ("our"?), that sets human ontology in checkmate. Ironically, the existence of the cyborg does not summon us to ask about the nature of the machines, but, much more dangerously, about human's nature: who are we? ? $^{5}$

As the above quotation indicates, once again the dichotomy may be addressing the reflection about the subject and the identity: human being vs. machine. This problem, though, still does not affect the epic manifestation of the discourse, which, for the time being, reveals new kinds of epic subjects, whose metonymical character points to a culturally healthy democratization of the heroic experience, as shown by the expressive number of feminine authorship epic productions generated mainly since the second half of the twentieth century. An excellent example of these new epic forms is South America. Mi hija (1991), by the American writer Sharon Doubiago (1941), in which a mother and her daughter can travel together through South America to discover their own truths and discuss their places in the world, although they note the persistence of many gender injunctions:

\author{
f. The Laughless Rock \\ In the earliest story \\ Isis was condemned to pregnancy, \\ To given birth in no time, no place \\ You wait for me to speak \\ My throat turns to stone \\ I want to say what all mothers \\ want to say to tier daughters. \\ What all mothers must say \\ To their daughters
}

\footnotetext{
${ }^{5}$ Original in Portuguese : "Pois uma das mais importantes questões de nosso tempo é justamente: onde termina o humano e onde começa a máquina? Ou, dada a ubiqüidade das máquinas, a ordem não seria a inversa?: onde termina a máquina e onde começa o humano? Ou, ainda, dada a geral promiscuidade entre o humano e a máquina, não seria o caso de se considerar ambas as perguntas simplesmente sem sentido? Mais do que a metáfora, é a realidade do ciborgue, sua inegável presença em nosso meio ("nosso"?), que põe em xeque a ontologia do humano. Ironicamente, a existência do ciborgue não nos intima a perguntar sobre a natureza das máquinas, mas, muito mais perigosamente, sobre a natureza do humano: quem somos nós? "(SILVA, 2000, p. 13).
} 
but are unable.

Why can't we speak?

Why do mothers betray their daughters

and thus themselves

all of life

the earth and all of time

the past and the future?

I am making the same betrayal

as my mother made of me

even now, though I have come this far with you

though you have come this far with me

though we have come this far together

though I have been thinking on this moment all your life

though you have waited all your life

though we know our necessary evolution

though you are raped, kidnapped,

though I hear you screaming

In you the secret turns to seed

In me, to stone

(DOUBIAGO, p. 34-35)

Doubiago dialogues with Greek tradition by referring the myth of Persephone. Each of nine parts of her poem is introduced with a poem on this myth, in a critical perspective that discusses the subalternity of the women. At the end of the trip, the lyric voice prays for a new relationship between men and women. As Aravamudan says:

Literary history, meanwhile, has often built its empires on the shaky ground of textual traditions. Furthermore, oceanic history takes maritime travel rather than territorial jurisdiction as its prime mover and therefore presents us with excitingly different notions of history and identity (ARAVAMUNDAN, 2019, p. 343).

In this perspective, Doubiago recovers and reinvents a Greek myth to resize issues of gender and opens space to a speech of contestation within the restricted and male space of epic production.

Our world chances all the time. Some changings are good. Another, don't, but we cannot stop these transformations. We can, however, reflect on them and change our attitudes toward the world. And as literary critics, we need to understand the evolution of literary genres and revisit productions such as epic poems, where the "subject" category is inserted in many new ways. However, it is possible that, later, considerations as Tomaz Tadeu da Silva's, mentioned below, will have to be retaken, so that the presence of much more "stranger" epic heroes and heroines can be analysed:

Implants, transplants, grafts, prostheses. Beings bearers of "artificial" organs. Beings genetically modified. Anabolic steroids, vaccines, psycopharmations. "Artificially" induced states. Pharmacologically intensified senses: perception, imagination, sexual arousement. Superatletes. Supermodels. Superwarriors. Clones. "Artificial" beings that overcome, located and partially (for the time being) the limited qualities and evident fragilities of the human beings. Machines with improved vision, with more agile reactions, with more accurate coordination. Improved war 
machines on both sides of the border: almost "artificial" soldiers and astronauts; almost human "artificial" beings. Biotechnologies. Virtual realities. Cloning that shuffle the distinctions between natural reproduction and artificial reproduction. Bits and bytes that circulate, indistinctly, between human bodies and electric bodies, turning them equally indistinct: human-electric bodies ${ }^{6}$

Driven by the myth, driven by the philosopher, driven by God, self-driven, socially driven, dispersed among his/her own and other people's fragments, driven by the machine, the subject, for all that has been seen, will always be a category in transit. In the same way, the presence of different types of anachronism in epic productions must be considered under an important fact: each creator will have its own way to be successful or not in artistic terms. As Highet recalls when he discusses the presence of the classical tradition in Western epic production:

If other times they acted correctly, it was because they came to the multiple irradiation of the classical past to intensify with it the bright solitary light of the present, and thus, with that strength that has only been given to the authors of fertile fantasy, they illuminated the whole majestic spectacle of human destiny?.

\section{Bibliography}

ARAVAMUDAN, Srinivas. The return of anachronism. Modern Language Quaterly, vol. 2, n. 4, December 2001, pp. 331-353, https://muse.jhu.edu/article/22906. Web 16 May, 2019.

BANTOCK, Gavin. Christ. A poem in twenty-six parts. Oxford: Donald Parsons, 1963.

BANTOCK, Gavin. Christos: Lovesong of the Son of Man: A Poem in Twenty-Six Parts. Unknown Publisher, 2106.

BHABHA, Homi K. O local da cultura [The location of culture]. Trad. Myriam Ávila, Eliana Lourenço de Lima Reis, Gláucia Renate Gonçalves. Belo Horizonte: UFMG, 1998.

CAMPBELL, Joseph. The power of myth. New York: Doubleday, 1988.

DOUBIAGO, Sharon. South America. Mi hija. Pittsburgh: University of Pittsburgh Press, 1992.

HALL, Stuart. A identidade cultural na pós-modernidade [The question of cultural identity]. Trad. Tomaz Tadeu da Silva and Guacira Lopes Louro. Rio de Janeiro: DP \& A., 2002.

HERNANDEZ, Alex Eric. Commodity and Religion in Pope's The Rape of the Lock. SEL Studies in English Literature 1500-1900, Volume 48, Number 3, Summer 2008, pp. 569-584.

https://muse.jhu.edu/article/245408/pdf. Web 14 May 2019.

HIGHET, Gilbert. La tradición clásica [The classic tradition]. V. I. Mexico : Fondo de Cultura Económica, 1954 (A).

\footnotetext{
${ }^{6}$ Original in Portuguese : “Implantes, transplantes, enxertos, próteses. Seres portadores de órgãos “artificiais”. Seres geneticamente modificados. Anabolizantes, vacinas, psicofármacos. Estados "artificialmente" induzidos. Sentidos farmacologicamente intensificados: a percepção, a imaginação, a tesão. Superatletas. Supermodelos. Superguerreiros. Clones. Seres "artificiais" que superam, localizada e parcialmente (por enquanto), as limitadas qualidades e as evidentes fragilidades dos humanos. Máquinas de visão melhorada, de reações mais ágeis, de coordenação mais precisa. Máquinas de guerra melhoradas de um lado e outro da fronteira: soldados e astronautas quase "artificiais"; seres "artificiais" quase humanos. Biotecnologias. Realidades virtuais. Clonagens que embaralham as distinções entre reprodução natural e reprodução artificial. Bits e bytes que circulam, indistintamente, entre corpos humanos e corpos elétricos, tornando-os igualmente indistintos: corpos humanos-elétricos" (SILVA, 2000, p. 15).
}

\footnotetext{
7 Original in Spanish: "Si otras veces obraron con acierto, fue porque acudieron a la múltiple irradiación del pasado clásico para intensificar con ella la brillante luz solitaria del presente, y así, con esa fuerza que sólo ha sido dada a los autores de fecunda fantasía, iluminaron todo el majestuoso espectáculo del destino human" (HIGHET, 1954A, p. 257).
} 
HIGHET, Gilbert. La tradición clásica [The classic tradition]. V. II. Mexico: Fondo de Cultura Económica, 1954 (B).

HUSAIN SYED AKHAR. Introduction. In: Bantock, Gavin. Christ. A poem un twenty-six parts. Oxford: Donald Parsons, 1966, pp ix-xiii.

KEATS, John. The Fall of Hyperion (1819). http://www.john-keats.com/gedichte/the_fall_of_hyperion.htm. Web 14 Jan 2019.

MACFAUL, Tom. "The Butterfly, the Fart and the Dwarf: the Origins of the English Laureate Micro-Epic".

Connotations: A Journal for Critical Debate. Volume 17 (2007/2008) Numbers 2-3, p. 144-164.

MILTON, John. Paraíso reconquistado. Paradise regained. Trad. Guilherme Gontijo Flores. São Paulo : Editora Cultura, 2014.

MÜLLER, Lutz. O herói. Todas nascemos para ser heróis [The hero. We were all born to be heroes]. São Paulo: Cultrix, 1997.

NEWEY, Vincent. Hyperion, The Fall of Hyperion, and Keat's epic ambitions. The Cambridge Companion to Keats. Ed. Susan J. Wolfson. Cambridge: Cambridge University Press, 2001, p. 69-85.

POPE, Alexander. The Rape of the Lock. An heroi-comical poem. Illustrated by Aubrey Beardsley. New York: Dover Publication Inc., 1968.

RAMALHO, Christina. Vozes épicas: história e mito segundo as mulheres [Epic Voices: History and Myth According to Women]. Rio de Janeiro: UFRJ, 2004.

RAMALHO, Christina. Epopeia e religião: fronteiras entre mito e história. Letras Escreve. https://periodicos.unifap.br/index.php/letras Macapá, v. 8, n. 3, 20 sem., 2018, p. 59-74.

SPENSER, Edmund. The fairie queene. London: New York: Routledge, 2006.

SILVA, Anazildo Vasconcelos da. A lírica brasileira no século XX [The Brazilian lyric in the twentieth century]. Rio de Janeiro: OPVS, 2002.

SILVA, Tomaz Tadeu da. Antropologia do ciborgue: As vertigens do pós-humano [Cyborg Anthropology: The Vertigo of the Post-Human]. Belo Horizonte: Autêntica, 2000.

The Rape of the Lock: A Mock-Epic. English Literature. Notes/Words: 825/January 29, 2020, https://englishliterature.net/notes/the-rape-of-the-lock-a-mock-epic. Web 15 February 2020. 